\title{
The system of Herbert Spencer's thought in its entirety: ${ }^{\dagger}$ The foundation of his educational ideas
}

\section{Introduction}

As the title of Spencer's Education: intellectual, moral, and physical (1860) suggests, physical education as a specific field of education can only be understood in its relation to education as a whole. Therefore it is necessary to elucidate Spencer's ideas of education as its foundation. However, his ideas of physical education have been considered by examining chapter 4 of Education, 'Physical Education', or considered in the context of Education at most. Although there has been reappraisal of his thought since Peel's work', attention mostly tends to be directed towards its sociological aspect. In the realm of education his ideas of physical education have seldom been discussed in its relation to his entire thought as a system. The reason for the necessity to take his system of thought into consideration in order to attain a better understanding of his ideas of physical education concerns the position of Education in his system of thought.

Spencer tried to describe ideal society in his works: for instance, Synthetic philosophy (186296) as his life work, consisting of about 6,000 pages, covers almost the whole realm of knowledge, that is to say, First principles (1 vol., 1862), Principles of psychology (2 vols., $1870-72)$, Principles of sociology (3 vols., 1876-96), Principles of biology (2 vols., $1864-67)$ and

\footnotetext{
†ハーバート・スペンサーの思想体系 : 彼の教育 思想の基盤として, 杉山英人 (筑波大学大学院).

†† Graduate School, University of Tsukuba.
}

Principles of ethics (2 vols., 1879-92). In these works Spencer attempted to find out the laws in each realm leading to happiness. In other words, the establishment of principles of right conduct for both each individual's and social happiness is the main theme of his philosophy. As Spencer himself maintained in Principles of ethics, his ethics is most important because the accomplishment of conduct relies on inner rule, i.e. morality.

As he clearly stated in Education (1860), he set up happiness or "complete living"2) as the supreme end. Here we see the identification of the end of education with that of his system of thought. Furthermore, the characteristics of his thought such as thorough laissez-faire, individualism, the stress on nature and "social organism"3) originate in Education. Spencer himself stated it in "The Filliation of Ideas". ${ }^{4)}$ The first importance in the standard of relative values in Education, i.e. self preservation is also considered as the one in Principles of ethics. For the above reason it is essential to clarify the foundation of Spencer's ideas of physical education not by examining them only in the context of Education but by examining the chief characteristics of his thought as the foundation of his educational ideas. And this study takes the first stage of the series of studies on Spencer's ideas of physical education, based on which the future studies focusing on his ideas of physical education themselves will be pursued.

Spencer's thought has been mainly characterized as liberalism and evolution. These characteristics have been pointed out as two conflicting aspects of his thought, i.e. radicalism and conservatism, which 
are also reflected in his educational thought. Trompf ${ }^{5)}$ described Spencer's educational thought to be "radical conservatism". However, these two are interdependent in order to realize happiness as the supreme end of his thought. Therefore it is important to consider each of these three aspects, i.e. liberalism, happiness and evolution, and their relation to education. For this reason this study consists of four main parts.

\section{Spencer's liberalism}

\subsection{Liberalism and justice}

As far as the concept of happiness as the supreme end is concerned, Spencer is a utilitarian as he considered himself to $\mathrm{be}^{6}$. The difference between Spencer and other utilitarians is particularly shown in the views of government. His thorough laissezfaire is mainly due to the fact that he wanted to realize individual's happiness based on individual's morality. In this sense he denied state intervention in an individual's realm of activity. His laissezfaire allows each individual to behave freely on condition that he or she does not infringe upon others' freedom. This idea places him in a peculiar position in the nineteenth century English liberalism. In the sense that he opposed state intervention, he could be regarded as a radical but his thoroughgoing laissez-faire itself obliges himself rather to be taken for a conservative in his days.

Social reform was the central idea in the main stream of Victorian liberalism. That era is characterized by the idea that laissez-faire could no longer be a useful weapon for solving social problems. Especially in the case of Spencer, as his laissez-faire is closely connected with the idea of evolution, he was obliged to deny the need for any social reform in the then received sense of the phrase. For him, the best policy was to leave people as they are for the natural process of laissez-faire to engender their progress.

State intervention was essential to reform: therefore the denial of such state intervention necessarily meant conservatism. For Spencer, state power is what leads us not to better but to worse conditions of society. He described it as "overlegislation"?). To put it briefly, legislation for social reform necessarily produces yet more legislation to amend the inefficiency of former legislation, thus finally all the legislation operating not for the sake of reform but for the sake of legislation itself. The more legislation, the less the place is left for individual's happiness because one has to adjust oneself to legislation. It can be said that Spencer's liberalism is very optimistic because he believed that individual free activity naturally led to a better state of society. It is certain that there is no such guarantee. He tried to justify it from the viewpoint of natural laws inherent in all beings: thus Spencerian freedom is operative in the sphere of those laws. The idea of evolution originates in the obedience to such laws. Particularly from the standpoint of evolution, laissez-faire was the only possible choice in the evolutionary process. Chronologically it is not to be denied that with Spencer the idea of laissez-faire precedes the idea of evolution. The former had already been formed in Proper sphere of government ${ }^{8)}$ and kept unchanged throughout his life. This was not contradictory to another significant concept, that of social organism.

This clearly reflects on the theory of social organism which is, needless to say, the social theory in which the organic laws are analogically applied. It has been said that this theory naturally reflects imperialism. One of his key terms, "the survival of the fittest"') used to be regarded as a typical example of it. However, he denied imperialism for its being nothing but the infringement upon national sovereign and the property of other countries. Therefore it is not quite the case, as it tends to be 
claimed that his idea of social organism means social imperialism. This is understandable from his fundamental principle, the administration of justice. As the essential requisite to laissez-faire he presented his idea of justice "to defend the natural rights of man ... to prevent the aggressions of the powerful upon the weak" ${ }^{10)}$.

His view of government also explains it. $\mathrm{He}$ admitted only two functions for government: to prevent both outside infringement and each individual's infringement upon right. He also stated the unjustness of colonization. He denied it even from the viewpoint of the benefit it brought to home country ${ }^{11}$. In 1917 Hugh Elliot asserted, "the main philosophic attacks upon the doctrines of militarism have come from English thinkers, and reached their climax last century in the writings of Herbert Spencer" ${ }^{12}$. The connection between imperialism and Spencer's thought is that the advocate of the former utilized Spencer's terms in order to justify it. That is why he came to justify himself that the fittest does not mean the best. He was even obliged to state that the laissez-faire and "the survival of the fittest" do not directly apply to human beings when he discussed the difference between animal justice and human justice in Principles of ethics, vol. 1.

It is known that Spencer criticized the Boer War as an example of imperialism. He expressed the foolishness of imperialism from the viewpoint of the essential connection between imperialism and slavery on the side of the oppressor. Imperialism is not only the infringement upon others' rights but it inevitably bears the bondage to the aggressors themselves. In proportion as liberty is diminished in the countries over which it rules, liberty is diminished within its own country. It necessarily produces the aggression of the state towards individuals by controlling their lives in order to maintain the colonies and prevent their rebellion.

It can be said that the country which enslaves other countries enslaves itself to maintain its life and power. For Spencer imperialism is the worst case of state infringement upon its members' right of freedom leading to the situation where each member is a serf to the state. Each member who has ability to use his or her powers for his or her own ends is obliged to use their abilities for state purposes. The members of the state have to be statelabourers indirectly by paying taxes and directly by carrying out services for the state. Imperialism leaves them less and less freed. Even imperialists have to submerge their personal liberties in the power of the state $^{13)}$. This is another reason why Spencer denounced the struggle for existence between societies as a cause of retrogression.

\subsection{Liberalism and beneficence}

As we have already pointed out, the proper sphere of government is to administer justice. He saw that justice had to be enforced by the incorporated society, the state. The function of the state is to perform ethical checks to prevent infringement upon others' right. This does not necessarily mean that laissez-faire is mere free competition among people. He condemned the miserable laissez-faire for leading people to ruin themselves in their attempt to enforce their equitable claims. He manifestly revealed the undesirable aspects of free competition leading to commercial murder and emphasized the idea of self-restraint in order to prevent such a miserable situation. Here we see the idiosyncrasy of Spencerian ethics. In Principles of ethics, vol. 2 he fully discussed both negative and positive beneficence as essential supplement to justice.

It is known that Spencer considered the results of the exercise of individuals' right of freedom as natural causation. He believed that if individuals were forced to compensate for others' failure of the exercise of their rights, it was nothing but 
infringement upon the human right. He paid much attention to this subject. He admitted the duty which fell on the superior of mitigating the evils which the inferior have to bear ${ }^{(4)}$. Each person of means ought to see the welfare of the particular inferior group to whom his circumstances put him in relation. This is the direct drive for social harmony. Therefore beneficence should be performed not by proxy but directly and spontaneously by individuals ${ }^{15}$. In other words beneficence is a private concern while justice is a state concern.

The main difficulty of this theory is concerned with the emerging problem of the working classes. Certainly he was aware of their miserable conditions. In his theory there were two ways to deal with this matter according to the idea of evolution. Firstly, he regarded the problem as a necessary part of the process of social evolution. Secondly, they were those in the lower ranks of society who deserved to be there. As Checkland states, "both <Malthus and Spencer> regarded those <working classes> at the bottom of society as being there because such a position reflected their true character and ability". The above view is also connected with another problem of equality.

The very idea that equality of opportunity was now greater had the effect of emphasizing in a new way the implication that those at the bottom of society were there because they were, in fact, basically inferior. It was beginning to appear that as equality of opportunity increases, inequality of natural endowment is made more apparent. Moreover, there was the fear of the fecundity of the slum dweller, the pauper, and the criminal, with which Spencer's system failed to come to terms. With the increasing concentration of the slums of the great cities, evolution seemed to operate in the direction of deterioration, as was remarked by observers who were struck by the apparent superior ability of thouse 'with low cerebral development' to multiply. Fears were expressed of the effects of 'interference with nature's selective mechanism' through the lowering of the death rate ${ }^{16)}$.

This is a weakness in his theory. As we have seen before, Spencerian social reform should be attempted not by any artificial means but directly by each individual. Social reform is to be brought about by reforming human nature. In this sense the process of education inevitably accompanies the process of social reform. This is the reason why Spencer's theory of social reform is "spontaneous reform". The best policy for social problems is to raise the moral character of a nation: it should be based upon each individual's morality. If the cause of social problem is too hard to be solved in a short term by any artificial ways such as legislation, stern repression or strict coercion, a solution arises by the gradual improvement by natural causation. Spontaneous means non-governmental. The idea of spontaneous reform is closely based upon his belief that a society is an evolution ${ }^{\text {(7) }}$.

\section{Happiness}

\subsection{Happiness and morality}

Such characteristics of his thought as laissezfaire, social organism and social evolution are interdependent for the realization of the ultimate end of individual's happiness to be pursued on the basis of each person's morality. His thought is considered as thorough individualism. There also emerges the importance of Spencerian ethics.

What we find in Spencer's egoism is a system ensuring the prospects of compatibility of interests among intelligent, good people, which 
should indicate why understanding ethics along egoistic lines makes very good sense. This is one reason why, of all the many volumes Spencer produced, his ethical writings are the most valuable and unorthodox. It is furthermore an advantage in these works that Spencer is concerned, not to defend his ethics via evolutionary science, but to work out the dynamics of an ethical position ${ }^{18}$.

Spencer regarded those who can actualize the compatibility of each individual's own interest as "the ideal man". Therefore the end of education is to make each individual an ideal person as a moral being who can follow the moral laws. There has been negative appreciation of his liberalism. It is useful as a means to prevent state intervention but not as a means to realize social reform. His laissezfaire may be appreciated from the viewpoint of morality, the most significant element in his ideas.

The crucial point in his thought is the relation between individual's freedom and his or her morality to realize complete living. This morality leads to the ideal society by which Spencer implied the accomplishment of each person's freedom. He presented the idea of "the law of equal freedom" as the first moral code. Morality is basically defined as means to follow the law. Thus he stressed the inner discipline rather than the outer regulation. It is clear in his writings that Spencer made morality significant in his whole system of philosophy. The importance of morality as well as laissez-faire penetrates his entire thought. The formation of his thought and the structure of his Synthetic philosophy demonstrate it. To consider the former briefly, it can be said that his philosophy is unchanged throughout his life. As Spencer himself often confessed in Autobiography ${ }^{19}$, his ideas developed from his substantially first pamphlet Proper sphere of government through his first book Social statics
(1850) to his life work Synthetic philosophy. The central idea through them all is to clarify what the right conduct leading to happiness is.

\subsection{Happiness, science and nature}

\subsubsection{Science}

The starting point of Spencer's thought was shown in Proper sphere of government. There he stated that "everything in nature has its laws" ${ }^{20)}$. The accomplishment of happiness is guaranteed only by following such laws. The importance of science and nature originates in this. The task of science is to find out such laws.

In the process of following the laws, nature has a very important role. In Spencer's words,

Man, as an animate being, has functions to perform, and has organs for performing those functions; he has instincts to be obeyed, and the means of obeying those instincts; and, so long as he performs those functions, as he obeys those instincts, as he bends to the laws of his nature, so long does he remain in health. All disobedience to these dictates, all transgression, produces its own punishment. Nature will be obeyed ${ }^{21}$.

This idea is fully developed in his Education, particularly in chapter 4 . As its subtitle shows, the book considers education from three essential elements of humanity.

As with man physically, so with man spiritually. Mind has its laws as well as matter. The mental faculties have their individual sphere of action in the great business of life; and upon their proper development, and the due performance of their duties, depend the moral integrity, and the intellectual health, of the individual. Psychical laws must be obeyed 
as well as physical ones; and disobedience as surely brings its punishment in the one case, as in the other ${ }^{22}$.

These three maxims are Spencer's basic view of humanity. There is the idea that there does not exist integrity of humanity before each sphere of duties (intellectual, moral and physical) has been duly performed. The natural laws in each area are to be found in science: therefore the main task of education is to let people understand such laws. In this sense the significance of science is stressed in his theory of education. It is certain that science is overstressed as a reaction against the classical education of his days, where science was almost neglected in school curriculum except in nonconformist academies. Spencer's critical remarks are especially directed to education in public schools. However, his emphasis on science is deeply rooted in the central principle of his reasoning stated above.

Spencer indicated it more clearly in chapter 1 of Education. As its title 'What knowledge is of most worth?' already suggests, he discussed the knowledge which made up the content of education. According to him, such a deplorable state of education as the lack of science and too much emphasis on classics arose because the curriculum was organized without any "standard of relative values" ${ }^{23)}$. Therefore what must be done in the first place is to set standards from which knowledge is to be arranged into curriculum whose end is to realize complete living. He proposed five standards: (1) direct self-preservation, (2) indirect selfpreservation, (3) the rearing and discipline of offspring (parenthood), (4) the maintenance of proper, social and political relations (citizenship), (5) the leisure part of life devoted to the gratification of the tastes and feelings (pastime or the miscellaneous refinements of life) ${ }^{24)}$. Knowledge is to be re-organized in accordance with the above standards in the curriculum. Knowledge relevant to these standards has educational values. The fundamental point is that knowledge should be scientific. What knowledge is of most worth? He definitely answered, "Science" ${ }^{25}$.

Spencer's attitude towards science is usually criticized for the following reason: The position of science in education is crucial. The problem is that what he meant by science is too specialized in some sense. His scientific education is rather a professional education. A typical example is seen in chapter 4 where the main subject is physical health. Needless to say, it directly relates to his first standard, which is the most fundamental part of education: knowledge relating to direct selfpreservation is physiology. He denied the mere memory of knowledge, i.e. the citation of knowledge. This is one of the main reasons why he criticized contemporary education. This point is also often mentioned in Autobiography ${ }^{26}$. The main characteristic of the method in his theory is not just to teach scientific knowledge but to let learners understand the causation of phenomena based on scientific knowledge ${ }^{27)}$.

Accordingly, it is not sufficient to teach useful physiological knowledge which leads to health. The cardinal theme in physical education is that learners should comprehend the mechanisms of physiological knowledge for health. For instance, to know how a disease occurs, we ought to be acquainted with the structure of the body, the mechanism of digestion, and so on. The question is whether we need technical knowledge such as minute anatomical and physiological knowledge. We can be healthy without such knowledge because we can consult a doctor. However, the importance of science in the curriculum is completely right. What he tried to do in Education is to avoid from the scientific view point any possible prejudice whatever. 


\subsubsection{Science as authority}

One of the reasons why Spencer criticized the mere memory of knowledge is that it can let children admit and obey the authority in general. When he explained his reasoning of some phenomena to Huxley, he said that unfortunately the ugly fact destroyed Spencer's beautiful reasoning. Spencer used not to pay enough attention to any established disciplines, biology for instance. To take another example. He read books not to learn the ideas developed in them but to obtain information for his own theory. When he found some facts which supported his theory, he took them up irrelevant to the context in which they were used. In that sense he did not make much effort to make his theory scientific enough.

It may be useful to note here the idea of authority in Spencer's philosophy. $\mathrm{He}$ usually refused authority in general, and yet the significance of authority in his ideas is apparent. His emphasis upon science (laws) definitely indicates it. It is seen in Spencerian thought in general but particularly in the relation between his two key words, "sense" and "science" in chapter 4 of Education. Such terms as the stress on nature and the obedience to natural laws in his ideas show that science is a cardinal authority for human beings which will lead to happiness.

\subsubsection{Science and nature}

Spencer also dealt with the relation between science and Nature. The term Nature has a special meaning in his thought. His idea of Nature is fully explained in rather an unscientific way in Social statics. This attitude towards the idea of nature came to change in his later works in order to make his ideas more scientific. There his idea of "Divine Rule" is still crucial. In First principles he considered the world from two viewpoints: "the unknowable" and "the knowable". It seems that he avoided the subject of the existence of God by such a division.

However, it is not correct to regard him as an atheist. He stated that God was the existence beyond our knowledge. Human beings recognize phenomena only in relation to God. What they recognize is not the essence of phenomena but merely the appearance of them. The true cause of phenomena is God's will. For Spencer the idea of Divine Rule is the unscientific justification of his laissez-faire, and evolution is the scientific one. For him Nature is the laws which exist behind phenomena. As shown in an expression such as "Nature will be obeyed", Nature has rather a divine implication which concerns the unknowable realm of human understanding. In this sense the idea of Divine Rule is not completely replaced by the idea of evolution in spite of himself. The main task of science is to clarify Nature or Divine Rule. For this reason science is not against Nature, but is necessary for allowing human beings to obey Nature for their own happiness ${ }^{28}$.

It is important to consider the relation between science and nature concerning direct selfpreservation. According to Spencer, there is not much to teach learners in the realm of direct selfpreservation. His educational theory is characterized as scientific education. The stress on nature is another essential attribute of his theory. It is his theory of natural causation which Emile Durkheim criticized in his l'education morale (1925). The significance of nature is nothing but the emphasis on our senses. He said that instinct, desire and sense exist $a$ priori in human beings. They indicate us the natural laws. They are innate guide of our conduct for happiness though they might seem to be opposite to rationality.

In chapter 4 of Education, Spencer considered physical health from such a basic human desire as appetite, sense of heat and cold, and desire for 
exercise. He regarded them as a natural inclination in childhood. We can attain physical health by following such an inclination. As these exist $a$ priori in human beings, there is hardly anything left for education to do. If we try to use artificial means against such desire and sense, it means disobedience to nature, in other words, disobedience to the Divine Rule. This idea relates to his theory of "over legislation" as well. The term was originally to describe an inevitable vicious circle of artificial social policy. He told us:

The laws of society are of such character, that natural evils will rectify themselves; that there is in society, as in every other part of creation, that beautiful self-adjusting principle, which will keep all its elements in equilibrium; and, moreover, that as the interference of man in external nature often destroys the just balance, and produces greater evils than those to be remedied, so the attempt to regulate all the actions of community by legislation, will entail little else but misery and confusion ${ }^{29}$.

"Equilibrium" is another key term in his thought. Health is synonymous with equilibrium. It is an ideal state of both the organic and the inorganic. In that sense this concept is an analogy between the organic and the inorganic, or society in particular. Spencer's theory of social organism is based on it. To be unnatural means the destruction of the selfadjusting principle. This is why Spencer's educational theory is usually regarded as natural education. It certainly seems to be a very optimistic idea because it tells us that we are able to be healthy simply by following our desire and sense. However, they cannot be the perfect criterion. To give one example of gluttony may be enough ${ }^{30}$. It can be considered that science is useful to check the immaturity or imperfection of human senses as the guide for conduct. In the sphere of direct self preservation, desire and sense themselves are appearance of natural laws. Therefore the chief message in this area is to let learners obey such natural laws reinforced by sciences (especially physiology in this case).

There exists a self-adjusting principle in the centre of Spencer's educational theory. As we have seen, it is apparent that sciences are the most crucial part of education in his theory. The stress on nature is to be understood rather in connection with the method by which we learn right conduct from natural causation. When the unnatural means are taken against natural laws, there must occur natural evils. These evils should be remedied on the self adjusting principle. The doer is to know that his or her behaviour leads oneself to badness and consequently he or she should avoid such an action in future. This is what Spencer meant by learning. The theory of natural causation has a positive meaning because if we set up some artificial constraint to avoid such natural evils, we do not learn anything. The criticism of this may be that it is too strong or even too dangerous a theory for children to pursue. Furthermore, we can learn natural causation without being involved in practice. What is clear here is that this theory is nothing but laissez-faire. The reason why such a theory of his has come about is that it is sustained by his God, Evolution.

\section{Evolution}

\subsection{Evolution and morality}

Morality, as already mentioned, sheds light on the structure of Spencer's works. His morality is inseparably connected with his individualism. Morality is essential to the latter. In Proper sphere of government he discussed, as the title suggests, the function of government in general from which he 
induced its artificiality; it dose not lead to human happiness even if it is built up for the sake of happiness. In other words, this small essay is his confession of individualism. He denied any kind of state intervention into individual activity ${ }^{31}$.

Spencer admitted the necessity of government though by no means in any positive sense. It emerges in the process of human progress. So far people have required and still requires it to protect them from each other's infringement. Its function is "simply to defend the natural rights of man-to protect person and property-to prevent the aggressions of the powerful upon the weak-in a word, to administer justice." According to him, "this is the natural, the original, office of government. It was not intended to do less: it ought not to be allowed to do more" ${ }^{32)}$. It means that humanity has not morally evolved enough to build up self-rule inside each individual.

To administer justice is the main theme in Spencer's social philosophy because it is the foundation of laissez-faire. For Spencer it means to administer "the law of equal freedom". What he tried in Social statics is to describe the principles of the ideal society based upon the law of equal freedom. This is the essential condition for each individual to pursue his or her own happiness. It highlights the significance of individual morality as self-rule. Such a term as "an ideal man" or "a perfect man" indicates the person who is moral enough to obey the absolute moral laws. It leads to the conclusion that there does not exist any individual's completely free activity before such morality has been attained among humanity.

Here again Spencer took a very optimistic position, for he justified individual's free activities throughout the process leading to the ideal society based on his evolutionary theory. In this sense he considered morality in the same way as the process of human progress. He believed in peaceful harmony in the world as the end of human progress. There was enough reason for him to think so in his own days because England was the motherland of what was later to be named the Industrial Revolution. In that sense he can be regarded as a historicist. As a historicist, however, that is to say, as a historic determinist, his theory will prove a failure as we shall see later ${ }^{33)}$.

His evolutionary theory can only make sense if it actually justifies the process by which laissez-faire is an essential means for progress. The criticism of his ethics comes from the same viewpoint, which considers it simply as "evolutionary ethics" ${ }^{34)}$. It is certain that his thought is characterized by evolutionary attribute: because the perfect person will emerge in the final destination of social progress. Social progress is a result of ethical progress. This idea permeates through his philosophy, from Social statics to Principles of ethics. This is why he regarded the history of humanity as that of civilization ${ }^{35}$. The evolutionary view is Spencer's way to achieve the ideal society.

\subsection{Evolution and the problems of Spencer's theory}

It seems that Spencer lived too long and he was betrayed by his own God, Evolution. He recognized the difficulty of his optimistic theory of evolution: that is why he was not very positive in applying his theories to practice. To take just one example, while he advocated complete suffrage in politics, he did not claim to adopt it as an actual policy for the reason that it was too early to give such political right to women because women had not been given enough opportunity to exercise it ${ }^{36)}$. It means that Spencer himself was not sure whether his theories might operate or not in practice. Therefore he had to be negative in point of the practicability of his theories.

He mentioned that the theory of evolution is not 
yet positive because humanity had not evolved enough. It can be adduced from this that human beings are always in the process of endless evolution. He stated that it was very natural for social problems to exist in a society in the process of evolution. Such problems will gradually be solved on "self-adjusting principles". This is the reason why he is regarded as a conservative. Hence this conservatism in Spencer is nothing but optimism.

As Spencer did not commit himself to the practical world, unlike his contemporaries such as Mill, he could continue to be optimistic about social problems. In other words he could believe in classical laissez-faire without stating actual social policies in order to remedy them ${ }^{3 n}$. Paradoxically, Spencer was responsible for the changing meaning of liberalism. Human beings have the rights of freedom and at the same time have responsibility for most of their conduct. "This implied that under conditions of political freedom, the suffering people experience can ordinary be said to be their own fault. This idea made the desirability of government along classical liberal lines quite intelligible"38).

The difficulty in his concept of liberalism lies in the fact that he rejected the idea of human freedom of will and therefore could not realize that "without the fact of human choice clearly demonstrated, the idea of political and economic liberty makes no sense at all ${ }^{\prime 39}$. This suggests the dilemma between determinism and the possibility of genuine human choices. "His politics suffers from yet another crucial difficulty. Spencer believes that although we all have natural rights, these rights do not take effect or come into existence before the emergence of the full development of human nature and society"(40). This evolutionary idea inevitably admits social problems as an evil necessity during the process of the progress of humanity towards perfection. This is why the Spencerian theory of social reform is not realistic but optimistic.

In his theory of evolution England was one of the most civilized or socially evolved countries in his days because the so-called Industrial Revolution occurred there as mentioned above. Civilization depends on the progress of science. The idea of evolution is established as the universal law to explain away all possible phenomena in his Synthetic philosophy. For these reasons he never changed or in a sense could not change his optimistic view. However, he did see a problem of his theory because he deplored imperialism even in such an industrialized country as England. Imperialism is in its essence opposed to civilization, for it is a renewed version of barbarism. He described it as "re-barbarization"

$\mathrm{Re}$-barbarization originates in the encroachment of state power upon an individual's sphere. In other words, this phenomenon reveals the subordination of individuals to the state, i.e. the decrease of individuals' freedom. Re-barbarization must be said to be inconsistent with his evolutionary theory. It suggests that so-called civilization does not mean the progress of humanity in point of morality. Consequently, the process of civilization cannot be compatible with the process of evolution. This is the main logical difficulty in his theory. Dormant nature can be exercised by its related circumstances during the process of human progress.

\section{Education}

As far as morality as self-rule is concemed, Spencer's ethics suggests the possibility of complete individualism in society. This directly concerns the end of education. The cardinal role of education is to make individual "an ideally moral man". Spencer clearly indicated the distinction between statics and dynamics of society. This is shown in the title of his first book, Social statics. He wrote: 
Social philosophy may be aptly divided (as political economy has been) into statics and dynamics; the first treating of the equilibrium of a perfect society, the second of the forces by which society is advanced towards perfection. To determine what laws we must obey for the obtainment of complete happiness is the object of the one, whilst that of the other is to analyze the influences which are making us competent to obey these laws ${ }^{42}$.

Social statics deals with the ultimate end of education while social dynamics deals with forces (the function of education) to reach the ideal state of society and its members. "The equilibrium of a perfect society" is the state of ideal society which Spencer tried to describe in his works and is equal to "the obtainment of complete happiness". Therefore the objectives of his social philosophy are at the same time those of education which he aimed to establish. Social happiness does not mean any particular content but includes various kinds of views of happiness because social happiness is coexistent with the happiness of each individual based upon his or her own idea of it.

Accordingly for Spencer no artificial or outside constraint of individuals for the sake of social happiness is conceivable. He put forward morality instead. That is why it is the main object of education to make human constitution "egoistic altruism". Such is the nature of the person who can realize his or her own idea of happiness by obeying moral laws upon individual's morality. In this sense Spencerian ideas, especially ethics, "can enhance our understanding of life in freedom, whatever our own arguments for the value of such a life." In other words, his ideas "can shed needed light on some of the intricacies of what is demonstrably the best perspective on the ethical and political aspects of human life, namely, the morality of rational self - interest and the politics of the free society"43).

The idea of egoistic altruism as the nature of a perfect man is the realization of complete living among individuals and such a person is a member of the perfect society which is in a state of equilibrium. Thus the analysis of a perfect man leads us to the understanding of the function of education in relation to the ideal society. Education is also related to "the forces by which society is advanced towards perfection". In this sense education is the dynamics of society as well. This aspect of education is naturally related to his idea of social progress or social evolution. The analysis of two aspects of Spencer's social philosophy: statics and dynamics is an important way to consider the ultimate end of and the function of education in the case of Spencer.

\section{Conclusion}

In this study we have seen the main characteristics of Spencer's system of thought from the viewpoints of liberalism, happiness and evolution. Liberalism and the idea of evolution are interrelated under the concept of happiness. The analysis of the concept of happiness as the supreme end of his thought leads to the understanding of the ultimate end of education. For the sake of realizing happiness Spencer set up the relative value order in which self-preservation is given the first rank. It is also of first importance in physical education because of its direct connection with health. Therefore the clarification of the meaning of selfpreservation in its relation to happiness will contribute to clarifying both the aim of physical education and its peculiarity in the realm of education. In this sense the next subject to be taken is to consider Spencer's concept of happiness focusing on self-preservation.

We have also pointed out the importance of 
morality as inner discipline of conduct for the attainment of happiness. In the realm of physical education sense and desire are regarded as the natural guide of conduct. Both morality and natural guide are regarded as the inner guide. This is also concerned with the relation between nature and science, i.e. the relation between natural prompting as inner guide and authority as outer guide. Accordingly in order to clarify the mechanism of right conduct in the case of physical education or self-preservation in particular, it is necessary to consider the relation among these three elements.

\section{Notes}

1) Peel, J. D. Y. Herbert Spencer: the evolution of a sociologist, Basic Books, New York, 1971.

2) Education, p. 12. Education consists of four articles originally published in three periodicals. Ch. 1. 'What Knowledge is of Most Worth?' was published in Westminster Review for July 1859, Ch. 2. 'Intellectual Education' was published in North British Review under the title, 'The Art of Education' for May 1854, Ch. 3. 'Moral Education' was published in British Quarterly Review under the title, 'Moral Discipline of Children' for April 1858, and Ch. 4. 'Physical Education' was published in British Quarterly Review under the title, 'Physical Training' for April 1859. The first publication of Education was in 1860 in America and in 1861 in Britain. The reason why it appeared first in America is as follows: when he tried to republish four articles on education in a book volume, the proprietor of North British Review refused to let him include the article contributed to that periodical. However, this interdict was of no effect in the United States and some of his friends in the States recommended him to re-issue his articles.

Therefore he passed his articles with revision to $D$. Appleton and Co. Cf. Education: intellectual, moral, and physical, D. Appleton \& Co., New York, 1910, pp. v- vi. American edition was published through the effort of Youmans. Cf. Kazamias, A. M. 'Herbert Spencer: prophet of individualism and scientific culture' in Herbert Spencer on education, Teachers Colleg Press (Columbia University), New York, 1969, p. 21 and pp. $51-2 n$. In 1861 an English edition was published by G. Manwaring, ibid., p. 21n.

3) The first appearance of this term was in the Letter 5 of Proper sphere of government. His full discussion of it is in "The Social Organism" first published in Westminster Review for January 1860. Cf. Essays: scientific, political, \& speculative vol.1, Otto Zeller, Osnabruck, 1969, pp. 265-307.

4) Duncan, D. Life and Letters of Herbert Spencer, Methuen \& Co., London, 1908, p. 533.

5) Trompf, G. W. 'Radical Conservatism in Herbert Spencer's Educational Thought' in British Journal of Educational Studies, vol. 17, no.3, 1969.

6) When Mill criticized him for not being a utilitarian, he replied that the difference between them lay not in the end of happiness but in the procedure to the end. Cf. Mill, J. S. Utilitarianism, edited by Warnock, M. Fontana Press, New York, 1962, pp. 319n, 320n and Spencer, H. Autobiography, Vol. 2, William and Norgate, London, 1904, pp.87-89.

7) Cf. 'Over- legislation' in Essays vol. 3, pp. 229-82.

8) It consists of twelve letters originally appeared in Nonconformist between 1842 and 1843 .

9) Spencer used this term in order to justify his idea of social progress by the analogy of biology. Later he recognized the vagueness of this term in social phenomena and came to abandon it. In Principles of ethics he only applied it to animal life.

10) Spencer, H. Proper sphere of government, London, 1843 , p. 5.

11) Cf. Letter 6 of Proper sphere of government and $\mathrm{Ch}$. 22 of Social Statics.

12) Eliot, H. Herbert Spencer, Greenwood Press, Conneticut, 1970, p. 2.

13) Cf. 'Imperialism and slavery' in Facts and comments, 
Books for Libraries Press, New York, 1970, pp. 157 71.

14) By superior and inferior Spencer meant that merit should be gained according to deserts. In this case the compensation is contrary to the fair relation between them, i.e. justice because it is to deliver the merit to those who do not deserve. The superior are those who succeed to exercise their faculties to get merit and the inferior are those who do not.

15) Cf. 'Evolutionary ethics' in Various fragments, Books for Libraries Press, New York, 1973, pp. 121-9.

16) Checkland, S. G. The rise of industrial society in England 1815-1885, Longman, London, 1964, p. 398.

17) Cf. 'Spontaneous reform' in Facts and comments, pp. $29-34$.

18) Machan, T. R. 'Introduction' in Principles of ethics (2 vols.), Liberty Classics, Indianapolis, 1978, p. 16.

19) Spencer, H. Autobiography, passim.

20) Spencer, H. Proper sphere of government, p. 3.

21) Ibid., p. 4.

22) Loc. cit.

23) Spencer, H. Education, p. 7.

24) Ibid., pp. 14-6.

25) Ibid., p. 84.

26) Spencer, H. Autobiography, passim.

27) Cf. Autobiography, Spencer regarded his father's teaching method as the best. He learned it when he had conversation with his father in his early days. His father used to ask him the reason for his answers and never allowed the statement that they were written in books. His attitude towards Spencer led him to doubt any kind of authority. Spencer's laissez-faire is partly due to his father and his family's religious background. See also Lamar, L. B. 'Herbert Spencer and his father' and 'The originality of Herbert Spencer: a footnote to "Herbert Spencer and his father" in Studies in English, vol. 32, 1953 and vol. 34, 1955

28) For Spencer science and nature are two consistent terms as the former is the means of clarifying Nature, or natural laws. In chapter 4 of Education he stressed children's natural behaviour and their desire for physical movement. He criticized gymnastics for its unnatural movements and advocated play as the natural outlet for children.

29) Spencer, H. Proper sphere of government, p. 5.

30) Cf. chapter 4 of Education.

31) In Social statics he stressed the only exception of state intervention, which is the land question. However, he changed his position of the subject later by stating that laissez-faire can also operate in such a matter. This change in his attitude clearly shows his ever- consistent belief in supremacy of private administration over public administration. On this point he was criticized by such a land socialist as Henry George. On Spencer's confusion in land question, see, Gray, T. S. 'Is Herbert Spencer's law of equal freedom a utilitarian or a rights based theory of justice?' in Journal of the History of Philosophy, vol. 26, no. 2, 1988.

32) Spencer, H. Proper sphere of government, p. 5.

33) Cf. Paul, E. F. 'Herbert Spencer: the historicist as a failed prophet' in Journal of the History of Ideas, vol. 44, no. 4, 1983.

34) Low-Beer, A. 'Introduction' in Herbert Spencer, Macmillan, London, 1969, p. 8. Peters, R. S. Essays on educators, George Allen \& Unwin, London, 1981, p. 54.

35) Cf. "Evolutionary ethics" in Various pragments, pp. $123-4,128$.

36) Cf. Gray, op. cit. pp. 266-7.

37) Taylor, A. J. Laissez-faire and state intervention in nineteenth-century Britain, Macmillan, London, 1972, esp. pp. $25-6$.

38) Machan, op. cit., p. 16.

39) Ibid., p. 17.

40) Ibid., p. 18.

41) Cf. 'Re-barbarization' in Facts and comments, pp. $172-88$.

42) Spencer, H. Social statics: or the conditions essential to human happiness and the first of them developed, Augustus M. Kelley, New York, 1969, p. 409, emphasis 
体育・スポーツ哲学研究 13 (1991) 1

added.

43) Machan, op. cit., p. 19.

1991 年 11 月 26 日採録 